\title{
ВООРУЖЕННЫЕ
} КОНФАИКТЫ И ВОЙНЫ

\author{
Саймонс Г.
}

\section{COMMUNICATION MANAGEMENT AND THE HUMANITARIAN WAR BLUEPRINT: THE LIBYA WAR}

\begin{abstract}
Аннотация. Communication Management has become a common tool in the arsenal of the West in the context of trying to build the pretext for war, and then controlling the information flows after the fighting has begun. It is an attempt to justify the seemingly unjustifiable, where reason and logic are distorted, and the use of emotion is actively promoted. In the 21st century, its use has come to be common place in the settling of scores and the advancement of national interest in international relations (Pashenstev \& Simons, 2009). Methodological basis of the research is a systematic, structural-functional, comparative political and comparative-historical approaches, methods of analysis, synthesis, observation, simulation, expert assessments. Certainly, one may now even speak of a blueprint for going to war being established. This has been gradually shaped and refined by events such as the 1991 Gulf War, 1999 Kosovo War and the 2003 invasion and occupation of Iraq.Libya gave the opportunity to operationalize the blueprint, which in political terms proved to be successful, in terms of managing the information environment in order to promote a dubious political agenda (going to war against Libya under Gadaffi). The current situation in Syria points to the urgent need to be able to understand and to counter these tactics.
\end{abstract}

Ключевыеслова: Конфликтология, внешняя политика, Аивия, геополитика, Сирия, информачионная война, идеология, интересы, ценности, безопасность.

r he war has, officially at least, come to an end in Libya and the country declared as being «liberated» (from the rule of Gadaffi) and «democratic». Corporate mass media have once again shown their complete inability to serve any kind of actual or real public interest in their coverage (DiMaggio, 2009), and the corporate owners of those mass media are with national politics, and look forward to the prospects of further spoils from yet another war of choice.
Yet, its very end, the war in Libya has raised more questions than it has answered. It is probably one of the most poorly managed information wars in recent times. However, these vital questions are not being raised in the mass media, which tends to remain silent on a number of obvious key issues. The huge gaps, between what was being said and practiced by NATO, are in plain sight for many to see.

One of the motivations for this article therefore, is to briefly raise those issues, which I believe 
need to be articulated. These include the various false and misleading statements made by NATO concerning why and how they were involved militarily in Libya, the very worrying nature (and largely ignored) nature of the National Transitional Council, some of the results of the conflict, and the emerging conflicts that seem to be forming and shall follow.

\section{LIBERAL WARS}

One of the issues that were recently debated was that of the notion of liberal wars. One needs to carefully ask the question, what exactly is a liberal war? This term has come to become some kind of brand, where it is uttered and the audience automatically understand (or at least assume to understand) what is meant. The fundamental flaw, as I see it, is that an action that is by its very nature inhumane can be considered as being «liberal». There is no use of logical or ethical argumentation to persuade your opponent, but the use of blunt force to beat them in to submission.

The nature of so-called liberal wars has been gradually evolving in the 20th and 21st centuries. There has been a move away from what can be termed as being negative motivations for going to war - to stop famine, to halt genocide and ethnic cleansing. Now we have such «wonderful» reasons as spreading democracy and «liberating» oppressed peoples. Thus the façade of a much more positive rhetoric and the appearance of a positive rather than negative international engagement appear before the public.

Another trend that seems to be emerging is the asymmetric nature of these «peaceful» wars. An alliance of numerous democratic Western countries aligned against some fanatical dictator, the disparity of military power obvious for those who choose to look - such as Iraq, Afghanistan and Libya. This takes some of the guesswork and unpredictability from waging war, but not all of it. Therefore, the chance of military success makes them easier to sell a quick and just «victory» to the domestic audience. However, eight months of war in Libya has shown that in spite of the overwhelming military superiority, things do not necessarily go smoothly. There is an academic theory that states democratic countries do not go to war with each other, but we can certainly witness them attacking other «non-democratic» states on numerous occasions.

These wars are generally pre-emptive, rather than preventative in nature, based upon, in many instances false and misleading information. You do not have to remember too far back, when the case was made against Iraq, the WMDs and links to terrorism that were so «sincerely» sold to the world (Simons, 2008; Simons, 2010). But these are after all good wars that are fought against bad people that are out there to harm us, because they hate our freedom and way of life. So we are told ... Every «good» war needs atrocities, real or imagined, in order to capture the public's attention and sympathy. The human dimension here revolved around the well-worn excuses of massacres of civilians and mass rapes (Taylor, 2003). «Washington is concerned by reports that forces loyal to Libyan leader Moammar Gadaffi are using rape as a weapon of war, the U.S. secretary of state said. [...] Susan Rice, the U.S. envoy to the United Nations, told the U.N. Security Council that Gaddafi was handing out Viagra tablets to his forces to encourage them to rape women. ${ }^{1}$ These claims, like the WMDs in Iraq and many other tales used by the US as an excuse to go to war and fulfil their self-appointed global «humanitarian» mission were based on very spurious allegations that were presented as facts to the world.

Libya has a number of other similarities with previous wars in this regard, in addition to the production of atrocity stories. We were told that there were people aspiring for democracy and freedom from the tyranny of Gadaffi. The brave underdog and the much stronger, evil and brutal dictator provide the black and white dimensions of good and evil for the coming spectacle. Thus there is a ready made script for the consumption and entertainment of domestic audiences.

All through the mass media, around the world, the headlines triumphantly proclaim a successful beginning in the latest war the West has initiated. With many echoes and similarities to previous wars fought, the necessity to protect the defenceless civil population that want to free themselves from a vio-

\footnotetext{
${ }^{1}$ Libyan Rape Claims Concern Clinton, UPI, http://www. upi.com/Top_News/Special/2011/06/17/Libyan-rapeclaims-concern-Clinton/UPI-35201308326250/, 17 June 2011 (accessed 15 August 2011)
} 
lent tyrant. And a favourite of a number of previous conflicts from Kosovo to Iraq, engaging in a limited war, where the superiority of «Our» airpower shall win the day; taking few (if any) losses ourselves, causing limited civilian casualties and wreaking complete destruction upon the enemy.

Jus ad Bellum has been established in the mass media, announced proudly by politicians in Europe and the United States. This war, as have many in the Post-Cold War era, is being fought in the name of humanity. The logic that is meant to flow from this is that it is a just war, one fought selflessly and for the good of the Libyan people. However, when one gets away from this noble rhetoric, can war be classified as being something that is noble and just?

The current cycle of politics and conflict is seemingly based upon short term political goals and greed, with a complete disregard for the long term impact and consequences. This makes the ultimate «end-game» a very unpredictable and probably an unpleasant prospect.

In less than one hour the UN Security Council voted on a course that has led to open war, and getting involved in a civil war. 10 voted for war and there were five abstentions. «All necessary measures to protect civilians $>$ was passed in an evening session that was marked by some concerns expressed, but no outright opposition (by using a no vote to block the resolution). ${ }^{1}$ Effectively, carte blanche has been given to the use of force on Libya.

Thus the United States and her allies now find themselves embroiled in a third war in a Muslim country, together with the de facto war against Pakistan's frontier provinces.

\section{REVOLUTIONS PAST AND PRESENT}

Recently, waves of political and social unrest have shaken the decade's old established authoritarian regimes throughout the Middle East and North Africa. The Neo-Cons have been hailing this as a successful confirmation of President George W. Bush's claim that the US-led invasion

\footnotetext{
${ }^{1}$ Security Council Approves «No-Fly Zone» over Libya, Authorizing «All Necessary Measures $>$ to Protect Civilians, by Vote of 10 in Favour with 5 Abstentions, Security Council SC 10200, http://www.un.org/News/Press/docs/2011/ sc10200.doc.htm, 17 March 2011 (accessed 23 March 2011)
}

of Iraq would led to an eventual wave of democracy in the region. ${ }^{2}$ This in itself seems to be rather overly optimistic as the dust has not even settled from the revolutions in Tunisia, Egypt, Libya and other countries.

The way that these revolutions were waged showed remarkable similarities with the Colour Revolutions that swept through the countries of the Former Soviet Union in the 2003-2005 period (Georgia in 2003, Ukraine in 2004 and Kyrgyzstan in 2005). These revolutions were fuelled by youth organizations and New Communications Technology (the internet and mobile phones), which were able to circumvent the cumbersome mechanisms of control that were wielded by the authoritarian regimes of the time. The object of the revolutions was to remove the President of the countries, yet leave the political body essentially untouched, thereby gaining the support of the political elite. Looking at the leadership of the revolutions, the «revolutionaries $>$ were all at one stage serving in the ranks of the governments that were overthrown.

They were also supported materially, logistically and financially by the United States. The messages and means of rallying mass support and participation were based upon the goal of inducing an emotional response from the publics they were messaging. These revolutions were hailed as being grass roots democratic movements, although the aftermath proved this to be far from the case. All of these countries have been racked by economic, social and political instability (even seeing the villain of the Orange Revolution in Ukraine being elected President).

There has been the element of slogans and messages that are designed and intended to attract the attention and support of an international public — these messages being composed in English and using messages designed for a foreign audience. In Libya one could even see a sign in English pointing the way to a Rebel international media centre, which draws attention to the significance paid to international opinion. There is also the evident use of slogans and symbols to rally the protestors on the street.

\footnotetext{
${ }^{2}$ KarlVick, Israel Has Faith MubarakWill Prevail, Time, http:// www.time.com/time/world/article/0,8599,2044929,00. html, 28 January 2011 (accessed 22 March 2011)
} 


\section{COMPETING VERSIONS OF THE FUTURE}

There seem to be two primary competing versions, predicting the future that awaits Libya after the fighting finally subsides. One of those predictions appears to be overly optimistic and the other predicts extremely negative trends to take hold. There have been many talks in the international community about shaping the future of this company, including the creation of the Contact Group on Libya.

So far there have been a number of meetings of the Contact Group on Libya, its fourth meeting in Istanbul in late August had delegations from over 40 countries attended. The latest meeting was in Paris, where «leaders of Libya $>$ s uprising were in Paris Thursday with delegates from 60 countries and world bodies to discuss a roadmap for Libya $>\mathrm{S}$ humanitarian, political and economic future. $\gg^{1}$ Creating such a group, and holding various meetings about dictating the future of this country (albeit with some representation from Libya), has similarities to events in the past, such as Tehran in 1943 and Yalta in 1945. As eloquently, and as beautiful as the spoken words and promises may be at this current time, it still does not bode well for the average Libyan.

However, this has not halted attempts to try and paint a rosy picture of Libya's future. One such example of this came with a plethora of new acronyms. Harlan Ullman, a commentator for United Press International, and is also chairman of the Killowen Group (advises leaders of government and business) and senior adviser at the Atlantic Council. He began by deriding the term BRIC countries (Brazil, Russia, India and China) as being a «virtual cliché» of the globes emerging economic dynamos. This is ignoring the basic fact that China already owns more than US $\$ 1$ trillion of US national debt and is starting to demand some conditions on their «investment.» During the height of the recent debt crisis in the US, President Obama threatened not to pay American servicemen, but made guarantees to the Chinese (http://www.

\footnotetext{
${ }^{1}$ Hennessy, S., Paris Conference Contemplates Libya's Future, Voice of America, http://www.voanews.com/english/ news/africa/Paris-Conference-Contemplates-LibyasFuture-128893123.html, 1 September 2011 (accessed 4 September 2011)
}

dailymail.co.uk/news/article-2020651/US-debtceiling-crisis-American-troops-Afghanistan-paid. html), which provides a clear case of the changing system of international politics owing to changes in the possession of economic power.

Coming back to the issue of a new set of acronyms created by Ullman in the name of political fairness, there were two: AII (Afghanistan, Iraq and Iran); LES (Libya, Egypt and Syria). Proudly announcing Libya, Egypt and Syria as the charter members of this new «club» that have been «drawn together by public rebellion against decades of autocratic rule.» He gives a warning further on that «what happens in each represents the Arab Spring and the budding of democracy or turns into winters of discontent and chaos remains to be seen.» But he remains mostly optimistic, and is careful to draw a distinct line between AII and LES countries. Ullman pointed to a number of historical warnings, and called for a need to be involved in deciding the future of countries or be prepared to accept the consequences.

In Iraq, April $>$ s euphoria over Saddam $>$ s fall turned into looting and violence exacerbated by the inexcusable and disgraceful failure to plan for the peace. Aside from the benefit of ridding the planet of a particularly unsavoury character, the majority of Iraqis aren $>t$ better off today; Iran has been the substantial benefactor whose influence has spread; and violence among Sunni, Shiite and Kurd is far from contained.

In Iran, the people celebrated the end of the shah in 1979. Ayatollah Khomeini, orchestrating the rebellion from safety and luxury in France, was the returning hero. And from an autocracy, Iran became a mullahocracy in the grips of a ruling council of theocrats not democrats. One could also cite the false expectations after Fidel Castro routed Cuban President Fulgencio Batista over Christmas 1959 and what happened since as a further warning. ${ }^{2}$

What the author seems to ignore is that in these cases, US involvement and interference in domestic affairs, which lead to an intolerable situation for many citizens. When citizens ultimately have

\footnotetext{
${ }^{2}$ Ullman, H., Outside View: The «LES» Countries, UPI, http://www.upi.com/Top_News/Analysis/OutsideView/2011/08/24/Outside-View-The-LES-countries / UPI-88941314181140/, 24 August 2011 (accessed 25 August 2011)
} 
nothing to lose that has seen the rise and success of regimes, such as the current one in Iran. What we are offered are shallow warning stories and further nonsensical words that are intended to serve as some kind of rhetorical bogeyman, whether this is Islamic Fascist or mullahocracy. They simply make no sense and demonstrate the ignorance of those who wield them. Ultimately he does acknowledge, after a decade of war and with no end in sight, citizens in the West are weary of war and this is likely to affect their appetite to be involved in another long occupation.

\section{THE WEST'S POTEMKIN'S VILLAGE: PUBLIC DEBATES IN THE MASS MEDIA}

A revolution began in Libya on 15 February 2011, initially the forces opposing Gadaffi were successful militarily. However, soon found to be on the defensive and outgunned. The UN Security Council Resolution 1973 gave carte blanche for the use of military force on Libya in the evening of 17 March 2011 (meeting closed at 1920), the military operation named Odyssey Dawn commenced by 0400 on 19 March 2011. ${ }^{1}$ Although there are strenuous claims that the airstrikes are not in any way in support of the rebels the nature of the zones being attacked and the targets indicates otherwise.

This is not the first time that airpower has been directed against Gadaffi. In 1986 the US attacked Libya, President Ronald Reagan justified the bombing as «the peaceful mission of America to counter the savagery of the brutal enemy wherever he threatens freedom. $\gg^{2}$ Once again, the doublespeak about the use of war for «peaceful» ends.

It is quite disturbing how the mass media coverage of Libya is progressing. I thought things were bad with the news on Iraq and Afghanistan, but somehow media have actually managed to sink the bar even lower. There is an absence of even any pretence at presenting balanced

\footnotetext{
${ }^{1}$ Associated Press, Gadaffi vow Long War After Allies Strike Libya, Herald Tribune, http://www.heraldtribune.com/ article/20110319/WIRE/110319411/2416/NEWS? Title=Gadhafi-vow-long-war-after-allies-strike-Libya, 19 March 2011 (accessed 23 March 2011)

${ }^{2}$ Alberto Gonzalez \& Dolores Tanno (editors), Politics, Communication and Culture, Thousand Oaks, Sage Publications, 1997, p. 15
}

coverage of this latest mass media spectacle. Once more the pro-war voice is amplified and the antiwar voice muted. A number of subtle, yet detectable techniques can be readily observed.

Everything that is said by Libyan authorities is stated and it is always said now that the information «has not been independently verified.» Yet when Western military or political officials are quoted there is no such proviso. Of course, it is naturally understood how honest they have been with the public on information concerning the Global War On Terrorism (GWOT) (Bennett et al, 2007; Simons, 2008; Zelizer \& Allan, 2002). Maybe it could in some regards be considered a good sign that at least the mass media have developed at least a selective understanding of their professional duty in publishing material from sources. However, this standard should be applied without prejudice, especially in time of war and not only against what is promoted as being the «bad» side of the event.

Thus the GWOT has been expanded even further, becoming a Global War On Despots and Tyrants (albeit a very selective one) as well as the well established brands of the Taliban and Al Qaeda or simply AQ. Once more the focus is on the tactical questions and not the strategic ones. Strategic questions are absent from the media - should we fight this war? The mantra of a just war is the message to the public that is repeated again and again. Instead, the focus has been on the tactical questions. How do we best fight this war? As it is a given in the mass media narrative that the war is a righteous one.

As with the Kosovo War in 1999, this war has been billed as one that is being reluctantly undertaken, somewhat of a burden for the Western alliance in the name of a good and righteous cause. Also similar to Kosovo is the frame of waging a limited war, where our fighting men will be in little to no danger or risk. This is to be a war that is to be fought from afar. It is a war that is fought with Tomahawk cruise missiles and airpower to enforce a no fly zone over Libya (at this stage). On March 212011 the New York Times announced that:

An American-led military campaign to destroy Col. Muammar el-Qaddafi's air defences and establish a no-fly zone over Libya has nearly accomplished its initial objectives, and the United 
States is moving swiftly to hand command to allies in Europe, American officials said Monday. ${ }^{1}$

This was in response to a rift that occurred in the unfolding media narrative, when events did not pan out as anticipated by politics and media alike. The early successes of the coalition against Gadaffi were cheered in the information sphere as the triumph of the oppressed masses yearning for democracy and freedom, and anticipating the «inevitable» end to the regime very soon. However, when the «inevitable» did not occur, and in fact Gadaffi rallied his forces and began to crush the rebellion the narrative shifted to one that urged the protection of the rebels from the wrath of the dictator, who had pledged to show no mercy.

There were also attempts by Sweden to get involved in the bombing. All of these funny polls are being conducted, which give the impression of public support for «intervention.» This morning they had a «debate» on TV 4 after the 0700 news. For the anti-war side a quietly spoken woman (grey mouse it is said here, non-descript person 'ordinary'), her opponent was a tall guy in a suit and loudly spoken, completely crowding her out. This so-called display of pluralism and debate on this issue was over even before it had begun. The much more adept public speaker, representing the pro-war side), was able to give a much more convincing presentation, not owing to the power and logic of his argument, but due to his ability to disproportionately project his voice and hence argument over the top of his opponent. Swedish TV managed to sink that little bit lower by the techniques used to reinforce the pro-war position further, with the use of interviews with Swedish military officials before and after the debate. There was a subtle but noticeable lack of partiality in the media reportage and their calls for a military contribution by Sweden, from a supposedly neutral country.

There have been a number of polls, which in a way echo the lack of serious public debate on the issue of military intervention in Libya. According

\footnotetext{
${ }^{1}$ Elisabeth Bumiller and Kareem Fahim, US-Led Assault Nears Goal in Libya, The New York Times, http://www. nytimes.com/2011/03/22/world/africa/22libya.html? $\mathrm{r}=1$ \&scp=1\&sq=US\%20-\%20led\%20assualt\%20nears $\% 2 \overline{0}$ goal\&st=cse, 21 March 2011.
}

to polls conducted in Sweden, by Demoskop on behalf of the yellow newspaper Expressen, 9 out of 10 Swedes support the UN's decision to intervene, and 65 per cent of respondents stated that Sweden should participate in the intervention. ${ }^{2}$ Polls are a means to convey a certain perception on an issue, rather than being a solid fact. At very best they can be considered as being indicative of public sentiment (depending on the size of the poll and the questions asked). However, in this instance it seems to give the impression of public consensus. Sweden, it seems, would be willing enough to throw away 200 years of neutrality and accumulated reputation that has accompanied this position on a venture that has been hastily assembled and poorly defined.

\section{THE DICTATOR \\ THAT EVERYONE CAN HATE}

For every «good» and «just» war there needs to be a media presentable object or subject that everyone can hate. In many regards, Colonel Muammar Gadaffi is perfect for the task. His past associations with terrorism, his «flamboyant» lifestyle when on foreign trips, the way he dresses and his behaviour, which seems bizarre at times, makes him the perfect candidate and object for misunderstanding and dislike. The clincher for his image as being a brutal dictator and a $\ll$ mad man» is the fact that he is not exactly photogenic, and appears to be mad. This mad image is easier to generate as there is no attempt to background or explain any potential cultural differences with a « Western» audience.

Alogic following from establishing someone as being mad is that they are incapable or reason and therefore cannot be negotiated or reasoned with in order to see «common» sense. Gadaffi has been dictator of Libya since 1969, when a coup brought him to power. Until the events of February this year there was no sign of a domestic opposition capable of toppling him. To survive in this region for as long as he has requires more than luck, and certainly skill and cunning. Not exactly the hallmarks of a

\footnotetext{
${ }^{2}$ Sofia Strandberg, Swedes positive to UN intervention in Libya, survey suggests, Göteborg Daily, http://webnews. textalk.com/goteborg-daily/news/swedes-positive-toun-intervention-in-libya-survey-suggests, 22 March 2011 (accessed 23 March 2011)
} 
mad man. So brutal, yes absolutely, as for a mad man I have strong doubts about that.

As for the future of Libya's dictator, there seems to be a lack of consensus on this issue too. On the one hand there are calls from Obama and Clinton that Gadaffi must go. Therefore this military operation can be seen in the context as a means with which to remove him (and certainly by targeting his residences). However, British Prime Minister Cameron, when speaking before the House of Commons ahead of a vote on the issue of military action ruled this out. «It explicitly does not provide the legal authority for action to bring about Gadaffi's removal of power by military means. $\gg^{1}$ Unfortunately the extreme vagueness of UN Resolution 1973 does not explicitly exclude it either!

Talk was intense on the issue of bringing Gadaffi before an international court on the charges of war crimes. ${ }^{2}$ This not only contradicts one of the narratives that the war is not intended to overthrow Gadaffi, it is also sheer hypocrisy. Gadaffi is being held responsible for the actions of his armed forces, certainly as Commander in Chief the responsibility does ultimately rest with him. However, this should then be evenly applied, rather than the current highly selective basis. On an equal footing and using these very criteria being called for now, President Obama should be investigated. As Commander in Chief of the US armed forces he is ultimately responsible for their conduct. The conduct of US soldiers with murdering unarmed Afghan civilians ${ }^{3}$ and the continued drone attacks in Pakistan that have killed numerous civilians over the years (the use of drone attacks has been increased by Obama). ${ }^{4}$ Or does the use of

\footnotetext{
${ }^{1}$ British PM Says No Authority to Topple Gadaffi, Space War, http://www.spacewar.com/reports/British_PM_says_no_ authority_to_topple_Kadhafi_999.html, $2 \overline{1}$ March 2011

2 Bruno Waterfield, The Telegraph, http://www. telegraph.co.uk/news/worldnews/africaandindianocean/ libya/8359861/Libya-Col-Gaddafi-to-face-ICC-war-crimesprobe.html, 3 March 2011 (accessed 23 March 2011)

${ }^{3}$ Marc Hujer, Did US Soldiers Target Afghan Civilians? War Crime Allegations Threaten to Harm America's Image, Der Spiegel, http://www.spiegel.de/international/ world/0,1518,717127,00.html, 13 September 2010 (accessed 23 March 2011)

${ }^{4}$ US drone strike «kills 40» in Pakistani tribal region, BBC News, http://www.bbc.co.uk/news/world-south-
}

such attacks on civilians not matter when the label «Taliban Suspects $>$ is used, which justifies the summary execution of civilians with no due legal process or right to recourse? There has also been remarkable little said, after a brief condemnation, of the brutal suppression of the unrest in Bahrain. Certainly there are no hints or threats of investigation by the international criminal court.

\section{SECOND THOUGHTS AND RIFTS}

However, everything has not progressed as smoothly as anticipated, and there have already been signs of discontent and suspicion surfacing in some spaces.

But I see the Arab League has just had a revelation. In spite of calling on the West for this attack, realities of modern warfare are starting to dawn upon them. There are second thoughts just days after it began. Apparently there are civilian casualties and they don $>t$ like civilians being attacked. Who could have predicted this outcome? The whole «show» is a rather ridiculous farce. The Arab League's Secretary General Amr Mussa went as far as to say «what has happened in Libya differs from the goal of imposing a no-fly zone and what we want is the protection of civilians and not bombing of other civilians. ${ }^{5}$

These second thoughts are based upon, what in effect is a form of Pavlovian Response that has been cultivated by the media coverage of the new «humanised» warfare. That is, the narrative that we in the West have superior soldiers and weapon technology, and we fight in such a way that minimises civilian casualties. The use of «smart $\gg$ bombs and the like has the public believing and the expectation that few (if any) civilians should be killed in a war. This narrative is certainly promoted by the military officials of this concept of War With a Human Face. However, it also means that when civilian casualties do occur, the backlash is immediate and in some cases hard, owing to the dissonance with public expectation.

There are also cracks appearing in the Western alliance where there is fighting over who should take over responsibility after the US leaves. Brit-

\footnotetext{
asia-12769209, 17 March 2011 (accessed 23 March 2011)

${ }^{5}$ UN Security Council Opens new Libya Session, Space War, http://www.spacewar.com/reports/UN_Security_ Council_opens_new_Libya_session_999.html, 21 March 2011
} 
ish Prime Minister David Cameron stated NATO should in a public statement, which was contradicted by the French Foreign Minister Alain Juppe, who stated that Arab League interests and wishes should be taken into account. Turkey who opposed the attacks stated that it does not want to see this war end with the occupation of Libya. Within the US ranks there is strife too, law makers are complaining that the act of war was committed by President Obama without the consent and approval of Congress, thereby exceeding his constitutional authority. ${ }^{1}$

Obama's apparent vision in seeing NATO as being the organisation to take the lead role from the US seems to be in trouble too. The Italian Foreign Minister Franco Frattini warned that if NATO did not take over quickly, Italy shall take back control of NATO bases on its territory. This situation has been made even murkier by Juppe who has talked of NATO taking a supporting role (and not the lead). ${ }^{2}$ Such statements not only demonstrate a very public rift in NATO and the US on how to proceed from here, but also there has been remarkable little thought put into how to manage the war from the opening phases of the shooting.

Russia and China, although stating their objection to the conflict, interestingly never used their votes to veto the resolution in the UN Security Council, have been upping their critical rhetoric. On 22 March 2011 Prime Minister Putin stated that although Gadaffi's regime was not democratic this was not reason enough to embark upon a military intervention. He also characterised the UN resolution as: «The resolution is defective and flawed. It allows everything [...] It resembles medieval calls for crusades. $>^{3}$ The rhetoric is quite hard,

\footnotetext{
${ }^{1}$ Elisabeth Bumiller and Kareem Fahim, US-Led Assault Nears Goal in Libya, The New York Times, http://www. nytimes.com/2011/03/22/world/africa/22libya.html? $\mathrm{r}=1$ \&scp=1\&sq=US\%20-\%20led\%20assualt\%20nears\%20 goal\&st=cse, 21 March 2011.

${ }^{2}$ AFP, NATO Struggles to Overcome Decisions on Libya Action, Space War, http://www.spacewar.com/reports/ NATO_struggles_to_overcome_divisions_on_Libya action_999.html, 21 March 2011

${ }^{3}$ Putin Rips «Medieval Crusade» in Libya, Reuters in The Moscow Times, http://www.themoscowtimes.com/news/ article/putin-rips-medieval-crusade-in-libya/433447.html, 22 March 2011.
}

but is in the end only symbolic. The real power, to veto the resolution, was not used.

There have been attempts and calls by the UN Secretary General Ban Ki-Moon to bring about a sense of unity in the international community.

$\ll$ Out of the terrible massacres of the previous decades in which the international community had been accused of doing nothing — those massacres included the genocide in Srebenica, Rwanda and Cambodia - after those terrible incidents, the world said never again. [...] It is imperative that on this measure the international community speak with one voice. ${ }^{4}$

His emotional rhetoric though is very easily invalidated by the use of logic and facts. Certainly the world does not want to see a repeat of the genocides that he has mentioned. But he implies that only intervention by the international community would have seen these dark episodes averted. But there are a number of problems with his emotional call, international presence was already established in both Bosnia and Rwanda at the times these massacres took place, but those peacekeepers stood aside and let it happen. The third case of Cambodia was brought to an end not by the «selfless $>$ intervention of democratic countries but by the invasion of Communist Vietnam. This makes a mockery of these attempts to justify the crushing of an open and pluralistic debate on an issue of such importance.

\section{NATO'S INVOLVEMENT: FICTION AND FACT}

The mandate given by the UN Security Council, which was essentially the mechanism that was used to try and justify an illegal action, was to protect civilians from attack by armed formations in Libya. Among the claims by NATO were that its mission was to protect civilians, it was only targeting military objects, it was not targeting Gadaffi, there was no regime change agenda, there was no arming of the rebel factions and no troops were on the ground. So, let's take a look at each of these claims by NATO, the rhetoric expressed and the reality of their actions.

\footnotetext{
${ }^{4} \mathrm{UN}$ chief defends Libya air strikes against doubters, Space War, http://www.spacewar.com/reports/UN_chief defends_Libya_air_strikes_against_doubters_9 $\overline{99} . \mathrm{html}$, 22 March 2011 (accessed 23 March 2011)
} 
NATO's mission was to protect civilians only. ${ }^{1}$ This gives the war of choice against Libya a thin veneer of a «humanitarian» mission. The intended impression here is to have something that is otherwise repugnant, organised killing and violence, all done in the name of a good and just cause. The double standard of many journalists, in how they treated sources of information differently is most evident here. Information from NATO and the National Transitional Council (NTC), i.e. the good guys in this war was accepted at face value and without double checking, presented as facts. That is in spite of a long history of deception, by NATO especially, in earlier military conflicts. Gadaffi and his followers, in other words the bad guys of this plot, had their statements questioned and ridiculed (as being mere propaganda for example).

Brigadier General Claudio Gabellini, from NATO's planning staff from Naples, stated that «all NATO targets are military targets.» He also claimed that NATO had no interest in targeting Gadaffi, not even knowing his whereabouts. However, a statement by Colonel Ahmed Bani, the rebel military spokesman, casts doubt on NATO's alleged «neutrality» in the conflict. With reference to NATO airstrikes, he said that «they are doing their jobs very, very well [...] We will need these airstrikes when we are planning to advance on the ground. $»^{2}$ This statement NATO is in effect engaged in a ground support operation for the forces opposing Gadaffi than in protecting civilians.

Yet there were plenty of journalists able and willing to produce propagandistic articles on NATO's prowess and care for Libyan civilians. One particularly abysmal article had a headline that gushed With «God's Eye view» on Libya, NATO Strikes. «Two F-16 fighter jets prowling the skies over Tripoli pinpoint a missile launch site near a building in the capital. They ask for clearance to drop a pair of 500-pound bombs. [...] This bombing past midnight Sunday highlights the complex choreography behind more than 2,500 air strikes

\footnotetext{
${ }^{1}$ To see the text of the resolution please see http://www. guardian.co.uk/world/2011/mar/17/un-security-councilresolution.

${ }^{2}$ Associated Press, Fox News, NATO Forces Pound Tripoli as Rebels Claim Gains in East, http://www.foxnews.com/ world/2011/05/10/nato-forces-pound-tripoli-rebels-claimgains-east/\#ixzzleca7E8y8, 10 May 2011 (accessed 11 May 2011)
}

conducted by the alliance over nearly four months in pursuit of Moammar Gadaffi's forces. $\gg^{3}$ This propaganda is meant to soothe any concerns of civilians in the Western states about killing Libyan civilians. However, to work, this relies on an almost absolute ignorance of the power of modern weaponry. Dropping 500 pound bombs is almost certainly going to lead to civilian casualties, especially if this is done within urban areas! No matter how precise these weapons are guided. Additionally, it is interesting to note that the journalists refer to NATO pursuing Gadaffi's military forces, rather than protecting civilians. The thin coating of lies and spin does not take much to uncover.

Credibility of the precision bombing narrative is further eroded by a number of articles about the level of bombings by NATO. ANew York Times article headline speaks for itself, NATO bombs Tripoli in heaviest strikes yet. In one day, 15 targets in the central city were bombed. ${ }^{4}$ Other stories also suggested a less than precise use of the so-called smart bombs. A bombing raid on the Libyan intelligence chief's private residence saw approximately 10 bombs dropped on a residential neighbourhood. ${ }^{5}$ This is neither a military target nor something that is directly threatening civilians. Although, the rationale that is used to try and justify this act is that the work nature of the person being targeted is a threat to civilians. Such logic though is working on a lot of assumptions and presumptions. It also ignores the fact that civilians and their dwellings will become, to use the military's politically correct term, collateral damage. Such rhetoric and logic ignores any sort of ethical or moral responsibility of war. For the greater part, journalists have allowed NATO's flawed public statements go unchallenged

\footnotetext{
${ }^{3}$ Staff Writers, AFP, With «God's Eye view $»$ on Libya, NATO Strikes, Space Wars, http://www.spacewar.com/reports/ With_Gods_eyeview_on_Libya_NATO_strikes_999.html, 12 July 2011 (accessed 1 August 2011)

${ }^{4}$ Burns, J. F., NATO Bombs Tripoli in Heaviest Strikes Yet, The New York Times, http://www.nytimes.com/2011/05/24/ world/africa/24libya.html, 23 May 2011 (accessed 24 May 2011)

${ }^{5}$ Staff Writers, AFP, Libya's Spy Master Home Destroyed in NATO Air Strike, Space War, http://www.spacewar.com/ reports/Libyas_spy_master_home_destroyed_in_NATO_ air_strike_999.html, 19 August 2011 (accessed 22 August 2011)
} 
and therefore they remain unaccountable. The sickening assessment of an article in the Financial Times illustrates this point well when the journalist concluded that few if any civilians had been killed in a very carefully managed air war by NATO.

As in the Kosovo War in 1999, Afghanistan in 2001 and Iraq in 2003, state mass media assets were deliberately attacked. This presents an interesting dilemma from countries that lecture the rest of the world about media freedom and protecting journalists. But it also highlights the issue of the importance of trying to achieve information dominance in time of war and to deny your enemy this opportunity. Although, this is usually caged in much «nicer» terms, such as their media is only used for propaganda argument. «NATO said Saturday that it had disabled three Libyan state television transmission dishes in Tripoli with airstrikes overnight, as the alliance took steps to remove the main instrument of Col. Moammar el-Gadaffi's propaganda from the airwaves. $\gg^{1}$ Irina Bokovo, the Director-General of UNESCO, rightly condemned this action. «The NATO strike is also contrary to the principles of the Geneva Conventions that establish the civilian status of journalists in times of war even when they engage in propaganda [...] Silencing the media is never a solution. Fostering independent and pluralistic media is the only way to enable people to form their own opinion.» ${ }^{2}$

NATO has an almost reflex response when it comes to accusations that they have hit civilians in air raids. Such an instance occurred in June 2011 when NATO allegedly carried out strikes on a «high-level command and control node», although it initially denied the strike. A Libyan government spokesman alleged that a number of children were killed in this raid. An allegation that was strongly denied by Canadian Lieutenant General Charles Bouchard, Commander of NATO operations in

\footnotetext{
${ }^{1}$ Kirkpatrick, D. D., NATO Strikes at Libyan State TV, The New York Times, http://www.nytimes.com/2011/07/31/ world/africa/31tripoli.html, 30 July 2011 (accessed 10 August 2011)

${ }^{2}$ Director-General deplores NATO strike on Libyan state television facilities, Media Services, UNESCO, http://www. unesco.org/new/en/media-services/single-view/news/ director_general_deplores_nato_strike_on_libyan_state television_facilities/, 8 August 2011 (accessed 24 November 2011)
}

Libya. «This strike will greatly degrade Gaddafi regime forces $>$ ability to carry on their barbaric assault against the Libyan people. ${ }^{3}$ Within a period of two days, NATO admitted to striking the wrong target. Bouchard was then forced to say that a missile was intended for a «military missile site», but had missed and «may have caused a number of civilian casualties.» He blamed «weapons system failure» and added that «NATO regrets the loss of innocent civilian lives. ${ }^{4}$ Another headline read NATO Admits Libya Airstrike, Not Civilian Deaths. Thus the reluctance to admit what is common sense. «ANATO official said the alliance was aware of regime allegations that 15 people, including three children, were killed but had no way of verifying them. $>^{5}$ This kind of makes one ponder and wonder then, how do NATO get such «accurate» kill figures from the drone strikes that are done in the remote tribal areas of Pakistan, if they cannot do so on Europe's doorstep?

One of the articles that perhaps reveal what is likely to be one the real intentions behind the air strikes, which have hit civilian objects was found in Deutsche Welle. «NATO forces are continuing to expand their airstrikes over Libya and its capital, Tripoli, as the pressure builds on the country's leader, Moammar Gadaffi, to quit in the wake of more high-level defections. ${ }^{6}$ This is in effect using military force as a means of psychological terror, in order to force people to leave Gadaffi, which implies that he was hardly the isolated dictator that he was painted to be.

\footnotetext{
${ }^{3}$ Staff Writers, AFP, NATO Says Bombed Libya Military Target, Not Civilians, Modern Ghana, http://www. modernghana.com/news/335669/1/nato-says-bombedlibya-military-target-not-civilia.html, 21 June 2011 (accessed 1 August 2011)

${ }^{4}$ Kirkpatrick, D. D., NATO Admits Missile Hit a Civilian Home in Tripoli, http://www.nytimes.com/2011/06/20/ world/middleeast/20libya.html, 19 June 2011 (accessed 31 July 2011)

${ }^{5}$ Staff Writers, AFP, NATO Admits Libya Airstrike, Not Civilian Deaths, Straits Times, http://www.straitstimes.com/ BreakingNews/World/Story/STIStory_682117.html, 20 June 2011 (accessed 1 August 2011)

${ }^{6}$ Benzow, G. \& Mara, D., NATO Extends Libyan Airstrikes as More Top Officials Defect, Arab World, Deutsche Welle, http://www.dw-world.de/dw/article/0,,15125157,00.html, 2 June 2011 (accessed 3 June 2011)
} 
One of the issues that came out clearly was the level of cooperation between NATO and NTC forces in the fighting. The level of cynicism and lack of tact in how this was carried out became gradually more observable as the war progressed. «Libya's new rulers urged the visiting leaders of Britain and France on Thursday to continue NATO airstrikes in the North African nation as rebels entered one of deposed dictator Moammar Gadaffi's last remaining strongholds. $\gg^{1}$ This implies that NATO is far from acting as a neutral arbitrator, protecting the lives of civilians in this conflict, but rather providing air support operations for the rebel ground forces. An added implication is that if the rebels could not take the last remaining positions unassisted by NATO airpower, then it is unlikely that they would have ever been capable of winning this war without the foreign help.

At times, media openly discussed the help given by NATO to the rebels, in spite of no UN mandate to become involved with any one side in the civil war. «The officials also said that coordination between NATO and the rebels, and among the loosely organized rebel groups themselves, had become more sophisticated and lethal in recent weeks, even though NATO's mandate has been merely to protect civilians, not to take sides in the conflict. $\gg^{2}$ Although this article raises the issue of violating the UN mandate, there is absolutely no criticism of this fact. In June 2011, a British official was quoted as saying «we will protect civilians by all means necessary while the UN mandate is in force, and that applies to everybody. If the NTC attacks civilians, the mandate would give the international community the grounds to intervene.» In response to this issue being raised, one rebel commander was on record as saying «We object to being threatened by our allies. They are taking part in military action only at our invitation. $>^{3}$ This is

\footnotetext{
${ }^{1}$ Kumar-Sen, A., Libyan Rebels Urge More NATO Airstrikes, The Washington Times, http://www.washingtontimes.com/ news/2011/sep/15/cameron-sarkozy-visit-post-gadhafilibya/?page=all, 15 September 2011 (accessed 16September 2011)

${ }^{2}$ Schmitt, E. \& Myers, S. L., Surveillance and Coordination With NATO Aided Rebels, The New York Times, http:// www.nytimes.com/2011/08/22/world/africa/22nato.html, 21 August 2011 (accessed 22 August 2011)

${ }^{3}$ Sengupta, K., We'll Turn Our Guns on Libyan Rebels if they Attack Civilians, NATO Threatens, The Independent,
}

hardly a very convincing argument for NATO's $\ll$ neutral» role in this war!

As the civil war came to its current bloody end in Sirte, it became apparent, that in spite of the fine statements and promises made above concerning the protection of all civilians, this was more about rhetoric than fact. The heavy shelling by the NTC ground forces and the continuous aerial bombing by NATO of the city was a direct military threat to civilians that were still trapped within the city. ${ }^{4}$ Thus this situation completely contravening NATO's UN mandate for being there. Yet NATO took absolutely no action to attack NTC artillery positions outside of Sirte that were firing into the town.

One of the denials that were often made was that there were no NATO forces on the ground, and that it was only air and naval forces being used. «With no troops on the ground in Libya, NATO relies heavily on images taken by surveillance planes and drones to identify targets. $\gg^{5}$ This statement is completely clear and has no ambiguity concerning its meaning, there are no troops on the ground. This appears to be another lie as other statements clearly contradict this assertion. «At the same time, Britain, France and other nations deployed special forces on the ground inside Libya to help train and arm the rebels, the diplomat and another official said. ${ }^{6}$ The second statement is also very clear, NATO ground forces have been deployed on the ground in Libya. After this «revelation», there were attempts to try and disguise this violation of UN Security Council Resolution 1973 by hiding the details with misleading definitions. $\ll$ In

http://www.independent.co.uk/news/world/africa/wellturn-our-guns-on-libyan-rebels-if-they-attack-civilians-natothreatens-2294933.html, 9 June 2011 (accessed 9 June 2011)

${ }^{4}$ Staff Writers, AFP, NATO, NTC Deadlier Than Kadhafi Diehards: Sirte Escapees, Space War, http://www.spacewar. com/reports/NATO_NTC_deadlier_than_Kadhafi diehards_Sirte_escapees_999.html, $\overline{6}$ October $201 \overline{1}$ (accessed $\overline{7}$ October 2011)

${ }^{5}$ StaffWriters, AFP, With «God's Eye view» on Libya, NATO Strikes, Space Wars, http://www.spacewar.com/reports/ With_Gods_eyeview_on_Libya_NATO_strikes_999.html, 12 July $201 \overline{1}$ (accessed 1 August 2011)

${ }^{6}$ Schmitt, E. \& Myers, S. L., Surveillance and Coordination With NATO Aided Rebels, The New York Times, http:// www.nytimes.com/2011/08/22/world/africa/22nato.html, 21 August 2011 (accessed 22 August 2011) 
an interview with the EUobserver website, an unnamedNATO official admitted Britain and France may have deployed troops in Libya, but said that it would be «unfair to call them NATO forces.»" Once more, there is an attempt to try and conceal the truth through the use of defining and redefining of words and meanings.

\section{TIMETABLES AND INEVITABILITY}

This war was billed as being one with an inevitable outcome, sooner or later Gadaffi would be ousted from power owing to the power of the forces aligned against. We were told that he was isolated and unpopular, his remaining supporters would soon abandon him. Yet this war lasted some eight months, and Gaddafi had supporters to the very end. During the course of the war two mechanisms were employed by NATO on a regular basis. One was the expectation by the public, and NATO employed expectation management in this regard to control this aspect, which is when a war begins there is an expectation for a foreseeable end to it. Iraq and Afghanistan have violated this principle of war, and seem likes wars without an end (in spite of various vague promises of withdrawal). Deadlines and anniversaries are highly symbolic and crucial in the highly politicised nature of modern warfare. The other concerns the use of the rhetoric of inevitability. That is an outcome is presented as a being a fait accompli.

To give just one example of the use of fait accompli, Defence Secretary Robert Gate's, stated in June 2011 that «It $>$ s just a question when everybody around Gadaffi decides it $>$ s time to throw in the towel and throw him under the bus.» $\gg^{2}$ The amount of time is not specified in this quote from Gates, and is avoided for good reason, as the war was expected to end much sooner than it did. $\mathrm{He}$ does give the aspect of the course of events to be inevitable, and beyond question.

British Foreign Secretary William Hague tried to create a space for political manoeuvring

\footnotetext{
${ }^{1}$ NATO Admits UKand France may Have Troops in Libya, RIA Novosti, http://en.rian.ru/world/20110829/166274046. html, 29 August 2011 (accessed 29 August 2011)

2 Staff Writers, AFP, NATO Hits Tripoli as Gates Says Kaddafi's Time is Up, Space War, http: / / www.spacewar.com/ reports/NATO_hits_Tripoli_as_Gates_says_Kadhafis time_is_up_999.html, 5 June $\overline{2} 01 \overline{1}$ (accessed 6 June 2011)
}

using emotional rhetoric to avoid the issue of strict deadlines. «We $>$ re not going to set a deadline. You $>$ re asking about Christmas and who knows, it could be days or weeks or months, (but) it is worth doing. $>^{3}$ As stated above, the war lasted much longer and NATO encountered more resistance from Gadaffi's forces than anticipated, therefore this is an attempt at expectation management. This is done by trying to emphasise the «worthiness $>$ of this war, but strictly avoiding any kind of time table.

The earlier statements were made during a time when there was no immediate foreseeable end to the war. However, when events seemed to finally turn in NATO's favour, then some forecasts began to be made. «Asked for an assessment a day after NATO allies extended the mission by another 90 days, Lieutenant General Charles Bouchard told a press briefing: $\ll$ I $>$ m highly confident we can complete this mission well within this timeframe.»"4 The end game scenario is painted by NATO, which then tries to capitalise on the perception of legitimacy as they are going to complete their mission within the extended 90 day UN mandate. The sense of inevitability of the finale is married with the deadline.

Bearing in mind that the UN mandate referred to protecting civilians only, there was a natural denial that there were any efforts to track or target Gadaffi. However, like a lot of the NATO narrative, there are many inconsistencies in terms of words and deeds. A Washington Times article quoted Marine Colonel David Lapan on this issue. «I've confirmed with folks at NATO and through the command structure that they are not involved in targeting any particular individual, that they are not involved in a manhunt.» Yet, as was pointed out in the same article, British Defence Minister, Liam Fox, stated that NATO

\footnotetext{
${ }^{3}$ Staff Writers, AFP, NATO Hits Tripoli as Gates Says Kaddafi's Time is Up, Space War, http://www.spacewar. com/reports/NATO_hits_Tripoli_as_Gates_says_ Kadhafis_time_is_up_999.html, 5 June 2011 (accessed 6 June 2011)

${ }^{4}$ Staff Writers, AFP, NATO Confident Libya Air War to End Within Three Months, Space War, http://www.spacewar. com/reports/NATO_confident_Libya_air_war_to_end_ within_three_months_999.html, 22 September 2011 (accessed 23 September 2011)
} 
intelligence and reconnaissance assets are being used to try and hunt Gadaffi down. ${ }^{1}$ Other contradictory messages from military and political actors also appeared in the media. The Commander of US Africa Command, General Carter Ham, stated that Gadaffi had very few men left fighting for him and that «it seems to me that his ability to influence day to day activities has largely been eliminated, probably not completely eliminated, but pretty significantly.» This differs greatly from what the NATO Secretary General, Anders Fogh Rasmussen, was saying. Sticking to the mantra, he stated that «remnants of Gadaffi's regime still constitute a threat to the civilian population.» Therefore NATO had a duty to continue to protect them while the threat remained. ${ }^{2}$ The difference between the military and political assessments seems to be related to the subjective political objectives, rather than an objective military analysis of the situation.

One final clue as to the lies told by NATO regarding Gadaffi not being a target was a triumphant announcement that vehicles that were likely to be carrying Gadaffi who was fleeing from Sirte was attacked. «A US defence official said Thursday a US Predator drone along with a French fighter jet had attacked a convoy of vehicles in Libya that Paris believed was carrying Moammar Gadaffi. $>^{3}$ Please explain to me how this action fits with the UN mandate of protecting civilians from attack? It is certainly the final nail in the coffin of the pure lie that NATO was acting as some kind of neutral actor for the protection and good of the Libyan people.

\footnotetext{
${ }^{1}$ Associated Press, Pentagon: U.S., NATO not in Manhunt for Gaddafi, The Washington Times, http://www. washingtontimes.com/news/2011/aug/25/pentagon-usnato-not-manhunt-gadhafi/, 25 August 2011 (accessed 26 August 2011)

${ }^{2}$ Staff Writers, AFP, Kadhafi Controls Few Forces, not a US Target: General, Space War, http://www.spacewar. com/reports/Kadhafi_controls_few_forces_not_a_US target_general_999.html, 14 September 2011 (accessed 15 September 2011)

${ }^{3}$ Staff Writers, AFP, US Drone hit Same Convoy Targeted by French Jet: US, Space War, http://www.spacewar.com/ reports/US_drone_hit_same_convoy_targeted_by_ French_jet_US_999.html, 20 October 2011 (accessed 21 October 2011)
}

\section{WHAT IS BREAKING THE LAW AND CONSTITUTION, IF NOT IN A «GOOD»CAUSE?}

One of the primary narratives of the war in Libya revolves around the issue of the adherence to rule of law, in addition to «human decency». That is, Libya and Gadaffi in particular, should follow the established legal guidelines pertaining to the use of military force. Yet another aspect of hypocrisy, something that was relatively downplayed by the mass media and certainly by politicians, were the constitutional requirements that were violated during the United States> war against Gadaffi's Libya.

In spite of being kept uniformed, let alone part of the process for some time neither the US House of Representatives nor the Senate pressed for the imposition of the 1973 War Powers Resolution. This act was designed to limit a president's authority over placing armed forces in a state of hostilities without a declaration of war by Congress, but still leaves the president with room to respond to attacks on US armed forces. At the very most, the president is able to engage in a war for absolutely no more than 90 days without the imposition of the War Powers Resolution. ${ }^{4}$ Operation Odyssey Dawn, the Pentagon's name given to military operations against Gadaffi, began on March 19 and ended on 31 October 2011. This far exceeds the constitutionally permitted time that requires the enactment of the War Powers Resolution.

So was this a mere oversight or accident? Perhaps the thought of the greater good by violating the US constitution prevailed at the time? Such theoretical considerations seem to be naive owing to some limited debate and comments from some sections of US politics. Representative Brad Sherman, Democrat from California clarified the situation and issue at hand. «It's time for Congress to step forward. [...] It's time to stop shredding the U.S. Constitution in a presumed effort to bring democracy and constitutional rule of law to Libya. $>^{5}$

\footnotetext{
${ }^{4}$ Tomkins, R., UPI, U.S. Congress Remains in Dark Over Libya, Space War, http://www.spacewar.com/reports/ US_Congress_remains_in_dark_over_Libya_999.html, 23 May 2011 (accessed 24 May 2011)

${ }^{5}$ Savage, C., Libya Effort is Called Violation of War Act, The New York Times, http://www.nytimes.com/2011/05/26/ world/middleeast/26powers.html, 25 May 2011 (accessed 26 May 2011)
} 
The comments by Sherman seem to reveal not only a sense of indignity about the illegal aspects of the war in terms of the constitutional aspects, but also lack of belief in the stated objectives of the war.

This lack of belief in the stated «moral» dimensions of the war is back up by some of the legislative actions that subsequently occurred. In May 2011 the US House of Representatives passed a $\$ 690$ billion Pentagon budget bill. However, there were conditions that came with it. The conditions included limiting the Obama administrations handling of detainees at Guantanamo Bay and forbidding the use of US ground forces in Libya. ${ }^{1}$ This shows a distinct lack of faith and trust between the executive and legislative branches of government.

Obama merely cemented the cynicism surrounding his receipt of the Nobel Peace Prize, through various attempts to try and hide violations of the US constitution, not to mention rules of war and the UN mandate through trying to hide in «grey» legal and descriptive definitions of roles and events. A 38-page report was sent to lawmakers, describing and defending the Libyan operations. The situation was characterised as «U.S. operations do not involve sustained fighting or active exchanges of fire with hostile forces, nor do they involve U.S. ground troops. $\gg^{2}$ However, these morally, ethically and legally dubious selffulfilling definitions seemed to cause some disquiet among legal advisers at the Pentagon and Justice Department. Two lawyers stated their opinion was that continued involvement in the war amounted to «hostilities», which was ignored in favour of legal council that did not characterise the war in this manner. The disagreement was downplayed as being a good example for democracy in action by the White House. ${ }^{3}$ However, what is clear only

\footnotetext{
${ }^{1}$ Staff Writers, AFP, US Lawmakers, Pass $\$ 690$ Billion Pentagon Bill, Space War, http://www.spacewar.com/ reports/US_lawmakers_pass_690_billion_Pentagon_ bill_999.html, 26 May 2011 (accessed 27 May 2011)

${ }^{2}$ Savage, C. \& Landler, M., White House Defends Continuing U.S. Role in Libya Operation, The New York Times, http://www.nytimes.com/2011/06/16/us/politics/16powers. html?pagewanted=all, 15 June 2011 (accessed 31 July 2011)

${ }^{3}$ Savage, C., 2 Top Lawyers Lost to Obama in Libya War Policy Debate, The New York Times, http://www. nytimes.com/2011/06/18/world/africa/18powers. html?pagewanted=all, 17 June 2011 (accessed 31 July 2011)
}

opinions that favoured an illegal course of action were listened, which was merely used as a means to give the appearance or façade of legitimacy to an illegal act.

\section{THE LIKELY NATURE OF THE NEW REGIME}

There have been a number of different warning signs about the likely sinister nature of the new regime that has taken control of Libya. One of the first points of contention is the «democratic» label that has been quickly assigned by selfappointed leading members of the international community. The basic question needs to be asked, what is so democratic about taking political power by armed force? There have been no elections, no mandate from the Libyan people. Starting from this premise, I shall outlay a number of different points. In spite of the fine and eloquent promises and reassurances from those Western politicians that have been deceiving the public so diligently.

In spite of the overriding narrative from Western politicians that the rebel movement that has succeeded Gadaffi is a democratic movement, there are a significant number of concerns that there are certainly non-democratic elements that stand to ultimately take political power. A short introduction to an article in The Australian sums up the situation that is unfolding. «'Who wants to join the mujahidin? The gates of jihad are open in Libya!» declares a message posted on a pro al-Qaida internet forum monitored by Western analysts. ${ }^{4}$ This article is very detailed in the various extremist Islamic-based groups that were seeking influence in Libya with the removal of Gadaffi. In some regards there are a number of parallels here with Iraq, the removal of a dictator paving the way for extremist elements to move in.

By September 2011, the growing concern about a possible takeover by the extremist elements. A number of concerns were even coming from inside the rebel ranks. Qatar had been noted as being very helpful to certain elements that have an established track record of extremist activity.

\footnotetext{
${ }^{4}$ Neighbour, S., Libya Ripe for Jihad's Rallying Cries, The Australian, http://www.theaustralian.com.au/ news/features/libya-ripe-for-jihads-rallying-cries/storye6frg6z6-1226044640098, 26 April 2011 (accessed 6 September 2011)
} 
This included shiploads of weapons that were destined for extremist factions. ${ }^{1}$ This seems to be a contradictory act, to support the rebels in Libya, when they are fighting wars in Afghanistan and Iraq, with some people and organisations that have links.

Actions should correspond with the rhetoric and slogans that are assigned to them. In other words, deeds must match the talk. One of the points in which the nature of the new Libyan regime showed its true colours, yet again, was the handling of Moammar Gadaffi after his capture in Sirte on 20 October 2011 he was beaten and summarily executed by his captors. A number of media outlets tried to minimise the damage that this crime would do by framing the event as being uncertain, such as allegedly, in very carefully chosen words and constructed sentences. Others, such as Financial Times, highlighted the brutal nature of the Gadaffi regime. Stories focussed on the «joy» and celebration of Libyans and world leaders at his death. Little attention was paid to the complete absence of due process. This should have been paramount owing the vast amount of propaganda that was used to paint the picture of democratic movement seeking freedom versus a brutal dictator.

The NTC tried to offer a weak and feeble excuse to counter the allegations that Gadaffi was murdered. At first they tried to claim that he was killed in crossfire. However, the various images and videos that were taken of the event already demonstrated quickly enough that this was yet another NTC lie. Gadaffi was shown being man handled and beaten in a frenzied crowd, and ultimately bullet holes in his head that suggested it was an execution that killed him. ${ }^{2}$ There were

\footnotetext{
${ }^{1}$ (1) Nordland, R. \& Kirkpatrick, D. D., Islamists> Growing Sway Raises Questions for Libya, The New York Times, http://www.nytimes.com/2011/09/15/world/ africa/in-libya-islamists-growing-sway-raises-questions. html?pagewanted=all, 14 September 2011 (accessed 15 September 2011)

(2) Sen, A. K., Rebels Fearful of Islamist Takeover in Libya, The Washington Times, http://www.washingtontimes. com/news/2011/sep/29/rebels-fearful-of-islamisttakeover/?page=all, 29 September 2011 (accessed 3 October 2011)

${ }^{2}$ Fahim, K., Shadid, A. \& Gladstone, R., Violent End to an Era as Gaddafi Dies in Libya, The New York Times, http:// www.nytimes.com/2011/10/21/world/africa/qaddafi-iskilled-as-libyan-forces-take-surt.html?pagewanted=all, 20 October 2011 (accessed 21 October 2011)
}

some brief, weak and basically symbolic calls by the United States and the UN for the NTC to provide more details on the death. ${ }^{3}$ This was not the first or last time that prisoners have been executed by NTC and the allied militias. Another high profile case occurred on 28 July 2011 when the former rebel military commander, General Abdel Fattah Younes was murdered in custody. Not to mention the dozens of bodies strewn around Sirte after the fall, some with their hands tied behind their back, murdered as well. ${ }^{4}$

However, the reactions by the NTC to investigate Gadaffi's murder and the numerous other cases are likely to remain investigated, in spite of some vague and illusive promises. Attempts to try and lay the blame for the murder of Gadaffi by his own supporters tend to support this less than optimistic forecast. ${ }^{5}$ Such a lack of accountability and sense of justice is likely to result in a lack of trust and suspicion in society towards the new regime, which is beginning to consolidate its power base in the country through creating a sense of fear.

Human rights groups have expressed concern over how the rebel forces have been conducting themselves in terms of crimes against civilians and lynching captured soldiers. In a series of articles, UPI outlined a number of concerns that were expressed by Amnesty International. «Amnesty International said civilians suffered most from crimes allegedly committed by forces loyal to the NTC. Several fighters loyal to fugitive leader Moammar Gadaffi were lynched after they were captured by

\footnotetext{
${ }^{3}$ Fahim, K. \& Gladstone, R., U.S. and U.N. Demand Details From Libyan Leaders on How Qaddafi Died, The New York Times, http://www.nytimes.com/2011/10/22/world/ africa/libyan-leaders-appear-to-wrangle-over-qaddafi-burial. html?pagewanted=all, 21 October 2011 (accessed 23 October 2011)

${ }^{4}$ Daragahi, B. \& Blitz, J., Libya's NTC Under Fire For Killings, The Financial Times, http://www.ft.com/intl/ $\mathrm{cms} / \mathrm{s} / 0 /$ f0ea02be-fe5a-11e0-bac4-00144feabdc0. html\#axzz1 epP0T1Le, 25 October 2011 (accessed 25 October 2011)

${ }^{5}$ Fahim, K. \& Nossiter, A., In Libya, Massacre Site is Cleaned up, Not Investigated, The New York Times, http:// www.nytimes.com/2011/10/25/world/middleeast/ libyas-interim-leaders-to-investigate-qaddafi-killing. html?pagewanted=all, 24 October 2011 (accessed 25 October 2011)
} 
rebel forces. $\gg^{1}$ Human Rights Watch made similar observations concerning war crimes committed by the rebel forces. Sarah Leah Whitson, Middle East and North African Director for Human Rights Watch stated «Revenge against the people from Tawergha, whatever the accusations against them, undermines the goal of the Libyan revolution. In the new Libya, Tawerghans accused of wrongdoing should be prosecuted based on the law, not subject to vigilante justice. $\gg^{2}$ Although UPI cover the story, there seems to be a sense of belittling the subject through the use of the word «fret» in the title, which has a trivialising effect. The New York Times also carried a story about the Libyan town of Tawerga, whose citizens in effect endured a form of collective punishment from the NTC forces after they took the town. ${ }^{3}$ There seems to be no effort to systematically investigate these grave allegations by the international mass media or politicians.

There have also been a number of documented cases of crimes against African peoples, by those forces that were opposed to Gadaffi. Some discussion circulated in the ranks that urged rebels not to take out acts of revenge against « brother Libyans», however, no such consideration was given Africans present in the country. Large numbers of migrant workers from sub-Saharan Africa were present in the country, but the main accusation (and justification) that was used to imprison and commit arbitrarily murder. The evidence against these people seemed to be the colour of their skin. The event that seems to have initiated this prejudice originated from when African mercenaries that were apparently used to quell the revolt in Tripoli in the early days of the civil war. However, since

\footnotetext{
${ }^{1}$ Libyan Rebels Accused of War Crimes, UPI, http:// www.upi.com/Top_News/Special/2011/09/13/Libyanrebels-accused-of-war-crimes/UPI-83181315922807/, 13 September 2011 (15 September 2011)

${ }^{2}$ Rights Group Frets Over Post-Gadhafi Libya, UPI, http:// www.upi.com/Top_News/Specia ... ost-Gadhafi-Libya/ UPI-83201320079633/, 31 October 2011 (accessed 7 November 2011)

${ }^{3}$ Fahim, K., Accused of Fighting for Qaddafi, a Libyan Town's Residents Face Reprisals, The New York Times, http:// www.nytimes.com/2011/09/24/world/africa/accusedof-fighting-for-qaddafi-tawerga-residents-face-reprisals. html? pagewanted=all, 23 September 2011 (accessed 25 September 2011)
}

this time «western journalists began arriving in the city a few days later [...] they found no evidence of such foreign mercenaries.» Those not lynched were imprisoned in appalling conditions, and their numbers far exceeded that of Libyan prisoners. ${ }^{4}$ Africans seemed to provide a readily available and easily identifiable group to persecute at a time when the NTC needed to show some kind of responsibility to protect vulnerable groups in Libya.

It is certainly no secret that a number of the NTC have links to extremist Islamic organisations. Abdel Hakim Belhaj, now in charge of a military committee that is responsible for keeping order in Tripoli, was in 2004 subjected to rendition on the request of the US. And now he has been re-branded as an ally of the US, the same ones that sent him to six years of hell in a Libyan prison. ${ }^{5}$ Therefore this sudden change of mind or at least rhetoric, appears to be very opportunistic and linked to short-term strategy.

The NTC and its Libyan allies have not shown restraint in terms of their desire and ability at disinformation and deception of international audiences through their public statements and orchestrated public spectacles. This was made a much easier task owing to a very obliging Western press that mostly publicised the words without analysis or question. Agood example of this occurred early on in the war, when a Libyan woman just happened to go to a hotel that was occupied by foreign journalists. She declared publicly that she had been raped by forces loyal to Gadaffi. The fact that of all of the places she could go was a hotel know to be full of foreign journalists, combined with the fact that she could be subjected to an honour killing by her own family (she is killed by her own family for bringing shame to them) makes this story extremely suspicious. One does not have to remember too far back to the claims of Iraqi soldiers tossing infants from incubators in Kuwait. Every «good» and «just»

\footnotetext{
${ }^{4}$ Kirkpatrick, D. D., Libyans Turn Wrath on DarkSkinned Migrants, The New York Times, http://www. nytimes.com/2011/09/05/world/africa/05migrants. html?pagewanted=all, 4 September 2011 (accessed 5 September 2011)

${ }^{5}$ Nordland, R., In Libya, Former Enemy is Recast in Role of Ally, The New York Times, http://www. nytimes.com/2011/09/02/world/africa/02islamist. html?pagewanted=all, 1 September 2011 (accessed 2 September 2011)
} 
war needs a good old fashioned atrocity story to ensure public support for an adventure that is fraught with ethical and moral shortcomings.

There was another good example of the use of disinformation and deception later on in the war, which also highlights the attention that is paid to the political dimensions of modern warfare. This was the bizarre incident when the NTC announced that they had captured one of Gadaffi's sons, Seif alIslam, who showed up soon after for his own press conference in a very non-captured state. This deception did serve its short term purpose though as 11 foreign governments recognised the NTC as the legitimate authority in Libya, at a time when there was a reluctance in the international community to take a stance on the war. The impression was conveyed that the war was about to end, by the implication of the NTC statement, meant that there was a perceived need to take a stance at the last minute and support the winning side.

Libya's slide into anarchy does not seem to have finished. In spite of being completely «liberated» the country is inundated with weapons throughout the population. The self-appointed liberators, in their numerous factions, terrify the local residents on a daily basis. ${ }^{1}$ This seems to be a prelude to a power struggle between the various factions that were in a loose coalition against Gadaffi. The various militias are not disarming and are not disarming. ${ }^{2}$ In spite of the NTC saying that these groups need to be kept armed at the present time, the reality appears to be that they are powerless to do anything about the situation. The question is, what is going to be the nature of the regime that finally prevails, mostly likely as a result of the barrel of a gun?

\section{THE RESULTS OF THE WAR OF CHOICE}

One of the likely benefactors of the war against Gadaffi's Libya is big business, and especially oil in-

\footnotetext{
${ }^{1}$ Daragahi, B., Gunfire and Fear Fill Tripoli's Security Vacuum, The Financial Times, http://www.ft.com/ cms/s/0/45de427a-0415-11e1-864e-00144feabdc0. html\#axzz1fRMjSYEU, 31 October 2011 (accessed 11 November 2011)

${ }^{2}$ Kirkpatrick, D. D., In Libya, Fighting May Outlast the Revolution, The New York Times, http://www.nytimes. com/2011/11/02/world/africa/in-libya-the-fighting-mayoutlast-the-revolution.html?pagewanted=all, 1 November 2011 (accessed 7 November 2011)
}

terests. They could hardly contain their glee during the war. Already on 23 August 2011 Libyan rebels stated that oil companies are «very interested $\gg$ in what was going on in Libya. The pre-war level of production in Libya is 1.6 million barrels of oil per day. Keith Roberts, the Finance Director at British Oil Services Group Petrofac stated that «obviously we>re going to be very interested in what they intend to develop. [...] We haven $>t$ found the right opportunity in the past and it $>$ s been a difficult country to do business in. ${ }^{3}$ From this statement it is obvious that oil companies have a stake in seeing the Gadaffi regime deposed to enable the possibility of a more «cooperative» regime to enable them to increase corporate profits.

In addition to the oil companies, other parasitic businesses were seeking to quickly jump onboard and earn profits from the misery that has been imposed upon the Libyan people. The New York Times ran an article about the new «prospects $>$ for Western businesses in Libya. The complete absence of any form of ethics was amply demonstrated in the article.

The guns in Libya have barely quieted, and NATO's military assistance to the rebellion that toppled Col. Muammar el-Gadaffi will not end officially until Monday. But a new invasion force is already plotting its own landing on the shores of Tripoli.

Western security, construction and infrastructure companies that see profit-making opportunities receding in Iraq and Afghanistan have turned their sights on Libya, now free of four decades of dictatorship. Entrepreneurs are abuzz about the business potential of a country with huge needs and the oil to pay for them, plus the competitive advantage of Libyan gratitude toward the United States and its NATO partners.

A week before Colonel Qaddafi's death on Oct. 20, a delegation from 80 French companies arrived in Tripoli to meet officials of the Transitional National Council, the interim government. Last week, the new British defence minister, Philip Hammond, urged British companies to «pack their suitcases> and head to Tripoli.

\footnotetext{
${ }^{3}$ UPI, Oil Majors Waiting for Libyan War to End, Dalje. com, http://dalje.com/en-world/oil-majors-waiting-forlibyan-war-to-end/378091, 23 August 2011 (accessed 25 August 2011)
} 
«There is a gold rush of sorts taking place right now,» said David Hamod, president and chief executive officer of the National U.S. - Arab Chamber of Commerce. «And the Europeans and Asians are way ahead of us. I'm getting calls daily from members of the business community in Libya. They say, «Come back, we don't want the Americans to lose out.» $\ll 1$

This paints a grim picture for the future of the Libyan people, especially when taking into account the behaviour and the results of oil, reconstruction and security firms in Afghanistan and Iraq. Additionally, presumably in a manner similar to Iraq, they are like to be robbed of their national wealth and assets. I wonder how long the «gratitude» of ordinary Libyan will remain for their «liberation» from Gadaffi?

If one was to take for granted what is being said by politicians and mass media, it would seem that the war was a complete success and that the Libyan people are now «liberated $\gg$ and able to enjoys the fruits of freedom. Various political «pillars > of the international community could not rush quickly enough to Tripoli to be seen with the new regime, and to try and take credit for a war that had not only been started, but finished as well (unlike the early predictions in the campaigns in Afghanistan and Iraq).

Both the UK Prime Minister Cameron and France's President Sarkozy rushed to Libya in September. Unlike the increasingly indifferent or hostile receptions that they get from their constituents back in their home countries, the friendly reception and praise from Tripoli seemed to stoke their egos. In the meantime, US President Obama heaped praise on the NTC at the UN. The way that these politicians tried to claim some kind of positive credit for events in Libya absolutely smells of a very desperate and needy (and in many regards cynical) ploy to try and make some quick political capital out of the war, and to try and frame it as a policy success. Public opinion did not support the war, which makes the political posturing and grandstanding about its «success $>$ seem out of place.

\footnotetext{
${ }^{1}$ Shane, S., Western Companies See Prospects for Business in Libya, The New York Times, http://www.nytimes. com/2011/10/29/world/africa/western-companies-seelibya-as-ripe-at-last-for-business.html?pagewanted=all, 28 October 2011 (accessed 7 November 2011)
}

In terms of the streams of information being carried by the international media in the information sphere, it was quickly apparent that the level of deception and disinformation was very high. I have enumerated a number of different examples, although not an inexhaustible list, by any means! However, how have journalists evaluated the situation and their performance in this recent war? In one rather surprisingly frank article in the New York Times, a number of the issues affecting the «truth» were discussed. «Truth was first a casualty in Libya well before this war began, and the war has not improved matters at all, on any side. [...] Information, or rather truthful information, is often difficult to come by in any war zone. Disinformation is a powerful tool that can be used to mislead the enemy, hide tactics, instigate fear or win public support. There is also the fog of war, the confusion in communications and the chaos of the battlefield that can obscure any objective understanding. $>^{2}$ Parallels were made with the lies and deception that was used in the Iraq War in 2003. This demonstrates the value that is placed in the role of information in influencing the political factors, which affect the outcome of wars (rather than individual battles of a war).

Another article probed even deeper into the role of information and Western media in promoting the cause of the insurgency. Questions were asked and the situation detailed, how had so-called sophisticated Western journalists been so easily fooled. This time the blame was being laid at the feet of the journalists and not the rebels.

«There is no better proof for the gullibility (or worse) of Western media than how easily they have been manipulated by rebel spokesmen for the Libyan insurgency. From Sunday through Monday evening for more than 24 hours, broadcast and cable media outlets reported the rebels had captured Saif Gadaffi and his brother Mohammad. Why did they believe and publicize these unconfirmed reports? Because the rebels told them so. No photos, no audio, no proof. We even heard that Saif $>$ s capture was confirmed by International Criminal

\footnotetext{
${ }^{2}$ Kirkpatrick, D. D. \& Nordland, R., Waves of Disinformation and Confusion Swamp the Truth in Libya, The New York Times, http://www.nytimes.com/2011/08/24/world/ africa/24fog.html?pagewanted=all, 23 August 2011 (accessed 24 August 2011)
} 
Court prosecutors who apparently believed what they were told too.

But seriously, what has happened to journalism? NATO quickly morphed from being a force to protect civilians under its UN and Arab League Mandate into - 15,000 sorties later — being the air arm of the rebel ground forces, casualties be damned. In the same spirit, it looks now like the Western media have become the propaganda arm of the insurgency. Or maybe it's just terminal laziness. [...]

Every armed conflict is accompanied by a propaganda war, and I don't blame the rebels for reporting gossip or lies or wishful thinking if it serves their aims. That's war. But I expect our supposedly free and informed and sophisticated journalists to be cynics and to ask the hard, unsentimental questions, so that we can all get some sense of what the actual facts are before making our judgments and can help the rebels deal with all he hard problems they will face after Gadaffi is gone.» ${ }^{1}$

This tract from the article reveals a significant betrayal of professional aspects of journalistic work and integrity. Not checking the sources of information (verification), not offering alternative points of view, getting too close to their subject. The question being, whether this was «just» a case of very poor workmanship or some other even bigger problem that has become ingrained in modern Western journalism. As it seems to be becoming increasingly common occurrence for journalists to undertake similar self-critical evaluations after many of the contemporary conflicts that have taken place, implying the establishment of a certain pattern or at the very least a complete lack of an ability to learn from past errors.

Broader arguments of the war and its justification involve elements of bettering human security for the people of Libya. As has been demonstrated above, the result is quite the contrary. The security situation for people in the wider area, including Europe, has been further compromised by more shortterm and short-sighted interference by NATO and the West. One of the results of the anarchy is that

\footnotetext{
${ }^{1}$ Barber, B. R., Western Media in Libya: Journalists or the Propaganda Arm of the Insurgency?, The Huffington Post, http://www.huffingtonpost.com/benjamin-r-barber/ western-media-in-libya-jo_b_933901.html, 23 August 2011 (accessed 24 August 2011)
}

the significant arsenals of Gadaffi were plundered. Of particular interest is the fact that at least 5000 (and perhaps as many as 10000) of the 20000 man portable surface to air missiles are missing. This includes Russian made SA-7s. ${ }^{2}$ The European Union's Count-terrorism Coordinator, Gillies de Kerchove, stated in September 2011 that Al-Qaeda in the Islamic Maghreb have «gained access to weapons, either small arms or machine guns, or certain surface to air missiles which are extremely dangerous because they pose a risk to flights over the territory.» ${ }^{3}$

This situation then, has some further potential implications and scenarios, which include a foreign presence in the country as a result of the very real risks brought about by the presence of uncontrolled weapon stocks, which has been facilitated by NATO interference in the country. This seems to be already happening in a limited manner. The US has sent a team of experts to help search for missing weapons, with an emphasis on the surface to air missiles. ${ }^{4}$ This seems to be the start, the question being, where shall this eventually lead to and end? The prognosis is not very promising with emerging events and trends in Libya and the West's solid history of incompetence and interference in other countries.

\section{LIBYA AS ANOTHER IRAQ}

A narrative that is eagerly suppressed by politicians is comparing and contrasting Libya with Iraq. There are a number of reasons for doing this,

\footnotetext{
${ }^{2}$ 1) Staff Writers, UPI, Alarm Rises Over Missing Libyan Missiles, Space War, http://www.spacewar.com/reports/ Alarm_rises_over_missing_Libyan_missiles_999.html, 4 October 2011 (accessed 5 October 2011)

2) Nordland, R. \& Chivers, C. J., Heat-Seeking Missiles are Missing From Libyan Arms Stockpile, The New York Times, http://www.nytimes.com/2011/09/08/world/ africa/08missile.html?pagewanted=all, 7 September 2011 (accessed 7 September 2011)

${ }^{3}$ Staff Writers, AFP, Qaeda Offshoot Acquires Libyan Air Missiles: EU, Space War, http://www.spacewar.com/reports/ Qaeda_offshoot_acquires_Libyan_air_missiles_EU_999. html, 5 September 2011 (accessed 6 September 2011)

${ }^{4}$ Staff Writers, AFP, US Team Seeking Missing Missiles in Libya, Space War, http://www.spacewar.com/reports/ US_team_seeking_missing_missiles_in_Libya_999.html, 14 October 2011 (accessed 17 October 2011)
} 
which are tied to the perception that this tends to generate. Firstly, Iraq (in spite of the upbeat rhetoric) is a failure for the US. Eight years of occupation, no gratitude from the Iraqi people for their US installed «democracy» and «freedoms», thousands of soldiers dead, tens of thousands wounded. Another element is that Iraq is seen by many as an occupation, which they do not want to see Libya perceived as also. For now, there are no large numbers of foreign troops on the ground.

Datuk Mustapha Yaakub, Bureau Chairman of Perkasa International, was very critical of NATO's attack on Libya. He was also very critical of the lack of any form of protest from Islamic organizations in the region (Arab League, Organisation of Islamic Conference and Gulf Cooperation Council). «A civil war will occur in Libya if Gadaffi >s successor possesses no charisma to bring together the various tribes, just like the inability of the late Iraqi president Saddam Hussein $>$ s replacement in providing the kind of leadership that could unite the Sunni and Syiah Muslims in that country.» ${ }^{1} \mathrm{~A}$ valid point is made insofar as in the view of war that is intended to bring about regime change, should consider the end result and answer the following question as a minimum. Is the situation of ordinary people going to be better or worse as a result of the war? If it is worse, then moral constraints should prevent any attempt to bring about change, even if they are a «dictator» or have some other nondemocratic label.

There were also words or warning from key figures from Western countries too. The former head of the British Army, General Lord Richard Dannatt, warned that NATO's campaign in Libya was reminiscent of the 2003 campaign in Iraq. He openly stated that it was a «very naïve hope that a lightening campaign would bring about change in power and that all would be well. $\gg^{2}$ The background and experience of Dannatt should make him a very capable judge of the situation, yet his voice as with other dissenting voices was largely shut out from public discourse in the pages and

\footnotetext{
${ }^{1}$ Libya Could be Like Iraq or Worse: Perkasa, MYsinchew. com, http://www.mysinchew.com/node/62683, 24 August 2011 (accessed 24 August 2011)

${ }^{2}$ Lord Dannatt: Libya «Echoes $>$ Iraq Campaign, BBC News, http://news.bbc.co.uk/2/hi/programmes / hardtalk/9495064.stm, 24 May 2011 (accessed 24 May 2011)
}

screens of corporate media. His comments seem to reinforce the idea of short-term thinking and planning of such military operations.

Iraqis have also offered their opinion on the issue. The New York Times interviewed a number of Iraqis about their experience of being «liberated $\gg$ and «democratised», and what this situation means for ordinary Iraqis (and could mean for ordinary Libyans). This quick and easy process that is given by Western politicians of the process does not match the reality of average people that are forced to live through the process.

The men said they had learned the hard way what they never understood living under decades of repression: that democracy is not just the absence of oppression, but that it also involves challenging concepts of tolerance, compromise and civic responsibility yet to take root in Iraq, or in Libya.

What emerged in Iraq after the fall of Mr. Hussein's government was a society of everyone for themselves, individually and in small groups, grabbing for what they could get - literally, through looting, and eventually through the political process. This has made many Iraqis weary of the chaos of Iraqi-style democracy. Increasingly, they want a strong hand — elected by the people — to wield power. $^{3}$

This new reality of living in a «democratic» country does not match the superficial rhetoric and deceit that is fed to the Western publics about the tremendous «successes > of the various military ventures in the Middle East and Central Asia. Extremely interesting additional comments made by those interviewed. «Do not trust expatriates who rush back to stake a claim in the new government. Avoid a parliamentary system. And do not ostracize members of the former regime, as happened in Iraq under the so-called de-Baathification policy.» ${ }^{4}$ In the likely upcoming power struggle, it shall be interesting to see how much of this balanced advice is to be completely ignored in favour of trying to shape yet another country that is compliant with US interests with the same failed policies and practices of the past.

\footnotetext{
${ }^{3}$ Schmidt, M. S., From a Few Iraqis, a Word to Libyans on Liberation, The New York Times, http://www.nytimes. com/2011/08/30/world/middleeast/30baghdad.html, 29 August 2011 (accessed 30 August 2011)

${ }^{4}$ Ibid.
} 


\section{DEMOCRACY AND FREEDOM FOR SOME, BUT NOT FOR ALL}

One of the matters that became most apparent in the rhetorical assault on Libya, and now Syria, is the issue of democracy and freedom. This has been waged in a very open manner, which reveals the deep rooted lack of consistency and hypocrisy in the message. Demands are made for Libyans and Syrians to enjoy «democracy» and «freedom», but there is no such talk for equal treatment of the people in Yemen or Bahrain for instance. If there are any objections, these tend to come in the form of a whimper, than any kind of moral or ethical protest that is genuine and should be taken seriously. Interesting the question has not been asked by the «dutiful» fourth estate as to why such an obvious differentiation of treatment of the same issue between different countries of the same region exists.

During the largely neglected abortive attempt at an Arab Spring revolt in Bahrain, which was ruthlessly crushed with overwhelming armed force, there has been little coverage, let alone protest at the continuing social and legal injustice there. For instance, doctors and nurses that treated wounded protestors were given terms of 5-15 years for doing their job, by treating those who sought medical help. Doctors Without Borders had its offices raided by security forces in $\mathrm{Au}$ gust 2011 and subsequently stopped working in the country. At the height of the protest security forces seized Salmaniya hospital! 'Yet there is no outcry from the self-appointed pillars of the «civilised world» Sarkozy, Cameron and Obama. The question needs to be asked, why? Are the people of Bahrain less worthy of a free and democratic life than Syrians and Libyans?

Yemen is another country, where the element of hypocrisy has become very open and obvious, for all to see. There have been numerous stories of the Yemeni government using overwhelming force against protestors, including airpower. Dozens of protestors are being killed in the streets. ${ }^{2}$ Just a cou-

\footnotetext{
${ }^{1}$ Goodman,J.D., Bahrain Court Hands Down Harsh Sentences to Doctors and Protestors, The New York Times, http://www. nytimes.com/2011/09/30/world/middleeast/bahrain-courthands-down-harsh-sentences-to-doctors-and-protesters.html, 29 September 2011 (accessed 30 September 2011)

${ }^{2}$ Staff Writers, AFP, Rival Forces Clash in Yemen Capital, Space War, http://www.spacewar.com/reports/Rival_ forces_clash_in_Yemen_capital_999.html, 29 September 2011 (accessed 30 September 2011)
}

ple of almost inaudible whispers from Washington when the excesses of the slaughter became a little too much to remain completely silent, but there is no threat of imposing no fly zones, economic or political sanctions. Human Rights Watch, one of the voices condemning events, called the UN response to events there as «apathetic». ${ }^{3}$

\section{WHERE ARE WE GOING FROM HERE?}

One disturbing headline in the New York Times gives a hint of what may be in store for the future - U.S. Tactics in Libya may be a Model for Other Efforts. ${ }^{4}$ Although there was a lot of downplaying the situation in Libya being transferred to Syria, the fact is that the US tried to begin in very much the same way with a resolution that was very similar to the one used to open the way for the military attack against Libya. Luckily, on this occasion, China and Russia used their veto powers to avoid a re-run. The US façade continued when, in response to their veto, US Secretary of State Hillary Clinton demanded that China and Russia explain their veto to the Syrian people. «We believe the Security Council abrogated its responsibility yesterday [...] The countries that chose to veto the resolution will have to offer their own explanations to the Syrian people, and to all others who are fighting for freedom and human rights around the world.» ${ }^{5}$ The level of cynicism and hypocrisy in Clinton's demand is incredible. If this was equally applied around the globe, the US would be in for doing a lot of explaining to different countries around the world, where it has interfered and cost lives of countless innocent civilians.

\footnotetext{
${ }^{3}$ UN Falling Short on Yemen, HRW Says, UPI, http://www. upi.com/Top_News/Special/2011/10/03/UN-fallingshort-on-Yemen-HRW-says/UPI-60931317665393/, 3 October 2011 (accessed 5 October 2011)

${ }^{4}$ Cooper, H. \& Myers, S. L., U.S. Tactics in Libya may be a Model for Other Efforts U.S. Tactics in Libya may be a Model for Other Efforts, The New York Times, http:// www.nytimes.com/2011/08/29/world/africa/29diplo. html?pagewanted=all, 28 August 2011 (accessed 29 August 2011)

5 Russia, China Should Explain Their Veto to Syrians - Clinton, RIA Novosti, http://en.rian.ru/ world/20111006/167427841.html, 6 October 2011 (accessed 6 October 2011)
} 
Coming back to the issue of Libya, there was a lot of back patting and self-congratulatory celebration for a «good» job done. The US flip-flopping continued here too, making it somewhat difficult to understand which version of the story was in fact true, if any. On 8 September 2011, the US thanked Britain and France for their «extraordinary $\gg$ role in the Libya campaign. ${ }^{1}$ Yet, by early October, the US was already criticising NATO allies that it cannot make up NATO shortfalls. This was in response to defence cuts, demanding that various countries «coordinate» with the US when making the decisions on reducing defence expenditure. ${ }^{2}$ However, if anything the US needs other countries more than other countries need the US currently, the various wars of choice around the globe mean that the defence capacity and capability is stretched to breaking point. Hence the attempt to make the Libyan campaign seem like a European-led operation.

\section{CONCLUSION}

In summing up the results of the Libyan War, the question needs to be asked, why was the execution of the communication management strategy so poor this time? Then answer to this question can be found in different aspects. First, relates to the practical and operational issue of mass communication, and the number of different actors that were in the messenger side. The basic dilemma applies, the more different actors or people that you have in any one particular political body the greater the diversity of opinion. In other words, there were many different political actors that constituted the coalition that attacked Libya, each with their own set of world views and values, which did not necessarily fit with the NATO message. Hence the result was a sense of a very split and divided organisation, owing to the absence of a commonly agreed upon message.

\footnotetext{
${ }^{1}$ Staff Writers, AFP, US Hails «Extraordinary» French, British Roles in Libya, Space War, http://www.spacewar. com/reports/US_hails_extraordinary_French_British roles_in_Libya_999.html, 8 September 2011 (accessed $1 \overline{2}$ September 2011)

${ }^{2}$ Staff Writers, AFP, After Libya, US Cannot Bail Out NATO Shortfalls: Panetta, Space War, http://www.spacewar.com/ reports/After_Libya_US_cannot_bail_out_NATO shortfalls_Panetta_999.html, 5 October 2011 (accessed $\overline{6}$ October 2011)
}

The second point touches upon the issue of politics. War has a tendency of heightening political sensitivity and reactions. By its nature it is something that is brutal and rather unpalatable for the general public. Therefore, political rhetoric needs to bill a war of choice in a very moral and ethical narrative in order to enable the chance of acceptance. A result of this is to create a readily apparent gap in terms of the public expectations that have been cultivated by the political sphere, and the bloody reality that is modern warfare. Thus a compliant mass media is required in order to try and perpetuate the myth for as long as possible. The political risks of going to war are different for different countries, owing to historical backgrounds and the shared values and beliefs of different societies. It results in some countries political leadership being much more cautious about going to war and how wars should be ideally fought. The loss of military personnel is a more sensitive political topic in some countries than in others too. However, the ability to hide these potentially harmful and counter-images and messages are more difficult to control in the age of the internet and social media. Abu Ghraib, Haditha, the Kill Team and many other US atrocities committed in the name of the War Against Terror testify to this new facet. The tactic then shifts to trying to crowd out those opposing and damaging information streams, to establish information dominance.

An established means or blueprint for creating a favourable information environment that promotes and gives the perception of a popular native demand for regime change. It is normally directed against a regime that is not compliant with political or economic demands that are forced upon it by Western countries and corporations. A concerted information war is initiated in the so-called free press of the West, which paints the picture of an oppressed majority rising up against a repressive and non-democratic political regime, only wanting basic freedoms, human rights and democracy. The underdog narrative is important for establishing sympathy for them. These rebels are depicted as being democratic and non-violent in character.

The negative aspects and characteristics of the targeted regime are highlighted to demonstrate the «need» for change. In the mean time, other countries with similar regimes, have those negative characteristics downplayed or ignored. What 
has been unfolding in Yemen, the similar use of force against rebels and protesters for example, yet there are no sanctions let alone military action initiated against this regime. The numbers of those opposing the favoured regime are minimised, and overestimated in the cases where regime changed is desired.

Material and technical support is provided by the West to support the opposition. This ranges from know how on organising unrest, the recent arrest in Egypt of an Otpor activist from Serbia tends to add credence to this aspect. Informational support, in terms of harnessing the power of corporate and state media in the West to support the efforts of the rebels, is another means to support, spread and sustain the unrest or at least give the impression of this to Western audiences. One can clearly see the use of continuity in the branding of revolutionary waves, the Colour Revolutions and now the Arab Spring. They give the impression of something that is spontaneous and a positive wave of «progress», all of which they are far removed from.

There is an attempt to legitimise Western interference in the domestic conflict, which is provoked and supported by the West, through such international instruments as the UN Security Council. This gives the façade of world consensus on the issue, which is then manoeuvred into direc- tions that were not mandated as has been amply demonstrated in the Libyan operation. In the lead up to the planned war, there is an attempt to try and paint the image of a reluctant West that must become involved on the grounds of humanitarian concerns and not self-interest. A reluctant hero to the rescue of an oppressed people that merely seek liberation from their oppressor and to enjoy what the rest of the free world does already.

Once the fighting begins there is an attempt to «clean» the war as much as possible. Only the brutal dictator kills civilians, NATO does not for instance. The deaths of civilians at the hands of the dictator are deliberate, whereas NATO inflicted casualties cannot be confirmed or are collateral damage. Iconic images and moments are sought to promote the idea of an inevitable result of the righteous war, such as the capture of key figures or the defection of key members of the regime under attack. The destruction and splintering of an otherwise cohesive regime is encouraged through the targeting, economically and militarily the assets (residential house and economic assets) of key people. This is a form of psychological warfare, which was also practiced in 1999 in order to break the resolve of the Milosevic regime and Serbian military in order to hasten the end to a war that had dragged out longer than anticipated.

\section{БИБАИОГРАФИЯ}

1. Bennett, W. L., Lawrence, R. G. \& Livingston, S., When the Press Fails: Political Power and the News Media From Iraq to Katrina, Chicago, The University of Chicago Press, 2007

2. DiMaggio, A. R., Mass Media, Mass Propaganda: Examining the American News in the "War on Terror", Lanham (MD), Lexington Books, 2009

3. Pashentsev, E. \& Simons, G. (Editors), The Rising Role of Communication Management in World Politics and Business, Moscow, Slovo Publishing, 2009

4. Simons G., Selling conflict in the 21st century: PR or advertising the way of public consent? in Topical Issues of Advertising: Theory and Practice: collection of Papers. Vol. II. / Editor-in-Chief A.V. Prokhorov. Tambov: The Publishing House of TSU named after G.R. Derzhavin, 2010, pp. 45-53

5. Simons, G., Mass Media and the Battle for Public Opinion in the Global War on Terror: Violence and legitimacy in Iraq, Perceptions Journal, Volume 13, Spring-Summer 2008, pp. 79-92

6. Taylor, P. M., Munitions of the Mind: A History of Propaganda from the Ancient World to the Present Day, 3rd Edition, Manchester, Manchester University Press, 2003

7. Zelizer, B. \& Allan, S. (Editors), Journalism After September 11, London, Routledge, 2002

8. Andrei Manoilo. "Revoluciones de los higos", elemento enfurecido o «caos controlado»? // Vida Internacional. Digest. 2011.pp. 148-16

9. Евсеев В.В. Сирийский кризис под углом российско-американских отношений // Национальная безопасность / nota bene. - 2013. - 6. - C. 111 - 121. DOI: 10.7256/20738560.2013.6.10128. 
10. Виноградова Е.А. Роль публичной Аипмоматии А ББА в урегулировании сирийского конфмикта // NB: МежАународные отношения. — 2015. - 1. - C.55 - 65. DOI: 10.7256/23064226.2015.1.12619. URL: http://www.e-notabene.ru/wi/article_12619.html

11. Манойло A.В. Роль стратегий управляемого хаоса в формировании нового миропорядка // Право и политика. — 2014. - 5. - C. 638 - 651. DOI: 10.7256/1811-9018.2014.5.11816.

\section{REFERENCES (TRANSLITERATED)}

1. Bennett, W. L., Lawrence, R. G. \& Livingston, S., When the Press Fails: Political Power and the News Media From Iraq to Katrina, Chicago, The University of Chicago Press, 2007

2. DiMaggio, A. R., Mass Media, Mass Propaganda: Examining the American News in the "War on Terror", Lanham (MD), Lexington Books, 2009

3. Pashentsev, E. \& Simons, G. (Editors), The Rising Role of Communication Management in World Politics and Business, Moscow, Slovo Publishing, 2009

4. Simons G., Selling conflict in the 21st century: PR or advertising the way of public consent? in Topical Issues of Advertising: Theory and Practice: collection of Papers. Vol. II. / Editor-in-Chief A.V. Prokhorov. Tambov: The Publishing House of TSU named after G.R. Derzhavin, 2010, pp. 45-53

5. Simons, G., Mass Media and the Battle for Public Opinion in the Global War on Terror: Violence and legitimacy in Iraq, Perceptions Journal, Volume 13, Spring-Summer 2008, pp. 79-92

6. Taylor, P. M., Munitions of the Mind: A History of Propaganda from the Ancient World to the Present Day, 3rd Edition, Manchester, Manchester University Press, 2003

7. Zelizer, B. \& Allan, S. (Editors), Journalism After September 11, London, Routledge, 2002

8. Andrei Manoilo. "Revoluciones de los higos", elemento enfurecido o «caos controlado»? // Vida Internacional. Digest. 2011.pp. 148-16

9. Evseev V.V. Siriiskii krizis pod uglom rossiisko-amerikanskikh otnoshenii // Natsional'naya bezopasnost' / nota bene. - 2013. - 6. - C. 111 - 121. DOI: 10.7256/2073-8560.2013.6.10128.

10. Vinogradova E.A. Rol' publichnoi diplomatii ALBA v uregulirovanii siriiskogo konflikta // NB: Mezhdunarodnye otnosheniya. - 2015. - 1. - C. 55 - 65. DOI: 10.7256/23064226.2015.1.12619. URL: http://www.e-notabene.ru/wi/article_12619.html

11. Manoilo A.V. Rol's strategii upravlyaemogo khaosa $\mathrm{v}$ formirovanii novogo miroporyadka // Pravo i politika. - 2014. - 5. - C. 638 - 651. DOI: 10.7256/1811-9018.2014.5.11816. 